\title{
ABORTION: AN INFRINGEMENT OF THE FOETUS' RIGHT TO LIFE IN ISLAMIC LAW
}

\author{
Alhaji Umar Alkali* \\ Azizah Mohd** \\ Nora Abdul Hak*** \\ Roslina Che Soh@Yusoff****
}

\begin{abstract}
Under Islamic law, the life of a human being is sacred and as such, no one is allowed to kill or bring an end to the life of another except in accordance with the law. Whether a foetus under Islamic law is entitled to enjoy this protection or not is a subject that is hotly debated by Muslim scholars. Abortion has a direct link to the right of the child to life because when abortion is done, it simply brings an end to the life of the human being in the womb that is in the process of development. Abortion is generally prohibited under Islamic law because it is tantamount to killing a human being that has not fully developed. Muslim jurists are not unanimous on the stage and conditions that can warrant the permissibility of abortion. This study therefore intends to employ a doctrinal analysis in its methodology to examine the respective views of jurists on abortion. The study examines the definition of abortion from the juristic and medical perspectives, the concept of abortion under Islamic law and authorities from the Qur'an, sunnah and scholars' views concerning abortion, situations under which abortion may be permitted under Islamic law and the position of the law in some Muslim states. The article ends with a conclusion and recommendations on the practical steps that need to be taken in order to ensure that children's right to life are well protected even before they are born.
\end{abstract}

Keywords: abortion, foetus' right to life, child protection, Islamic Law

Corresponding Author, Ph.D. candidate, Ahmad Ibrahim Kulliyyah of Laws, International Islamic University Malaysia.

** Associate Professor, Ahmad Ibrahim Kulliyyah of Laws, International Islamic University Malaysia.

*** Associate Professor, Ahmad Ibrahim Kulliyyah of Laws, International Islamic University Malaysia.

**** Assistant Professor, Ahmad Ibrahim Kulliyyah of Laws, International Islamic University Malaysia. 


\title{
PENGGUGURAN: PELANGGARAN HAK JANIN UNTUK HIDUP DALAM UNDANG-UNDANG ISLAM
}

\begin{abstract}
ABSTRAK
Dalam undang-undang Islam, kehidupan seorang manusia di anggap suci dan olehkerana itu, tiada yang dibenarkan membunuh atau mengakhiri kehidupan seorang yang lain kecuali mengikut undang-undang. Menjadi satu pendebatan yang hangat di antara para ilmuan Muslim samada undang-undang Islam memberi perlindungan ini kepada janin.Pengguguran mempunyai talian langsung kepada hak seorang kanak-kanak untuk hidup kerana apabila pengguguran berlaku, ianya mengakhiri kehidupan seorang manusia di dalam rahim yang sedang dalam proses tumbesaran. Secara amnya, undang-undang Islam melarang pengguguran kerana ianya bagaikan membunuh seorang manusia yang belum lagi sempurna tumbesarannya. Para fuqaha tidak sebulat suara berkenaan tahap dan syarat yang dapat mengharuskan pengguguran. Kajian ini menggunapakai metodologi analisa doktrin dalam mengkaji pendapat-pendapat para fuqaha tentang pengguguran. Kajian ini mengkaji takrif pengguguran dari perspektif pakar perundangan dan perspektif perubatan, konsep pengguguran dalam undang-undang Islam dan hujah dari Al Qur'am, sunnah dan pendapat ulama-ulama tentang penguguran, situasi-situasi dimana pengguguran diharuskan di dalam undang-undang Islam dan keadaan undang-undang di beberapa negeri Islam. Makalah ini diakhiri dengan kesimpulan dan saranan tentang langkah-langkah praktikal yang harus diambil bagi memastikan perlindungan terhadap hak kanak-kanak untuk hidup walaupun sebelum mereka dilahirkan.
\end{abstract}

Kata kunci: Pengguguran, hak janin untuk hidup, perlindungan kanakkanak, undang-undang Islam

\section{INTRODUCTION}

Abortion is an issue that requires serious attention due to the fact that it terminates the life of a human being or foetus before it is fully developed. Though abortion cannot be equated to the act of killing a human being, it is however necessary to treat issues of abortion with all the seriousness it deserves due to its direct connection with the right to life. Under Islamic law, the moment an egg is fertilised in the womb, 
it is given certain rights. Allowing the foetus to fully develop and born alive is an indication of respect for the right to life. Generally, abortion is prohibited under Islamic law. ${ }^{1}$ Couples are at liberty to control and undertake family planning measures. However once the woman conceives, they cease to have the right to discontinue the pregnancy. When a person does abortion, Islamic law has prescribed the payment of blood money to the relatives of the aborted child. Muslims believe the anger of God and His punishment equally awaits any person that has voluntarily makes or causes abortion.

Muslim scholars are however not unanimous on the reasons that will make abortion lawful in the eyes of the law. Threat to the life of the mother is generally believed to be a justification for legal abortion. This position is predicated on the assumption that it is better to take the lesser evil. In other words, it is better to lose the unborn child than losing the mother. Considering rape as one of the grounds to allow abortion has been hotly debated by Muslim scholars. ${ }^{2}$ The period or stage at which such abortion can be permitted has equally been a subject of discussion. Under the Shari'ah, it is generally believed that life is breathed to the foetus after 120 days of conception. To that effect the prohibition of abortion especially after the 120 days becomes even more serious and the blood money to be paid for such becomes higher.

This article therefore examines abortion as it affects the right of the child to life. Opinions of Muslim jurists on the prohibition and exceptions to abortion is equally discussed and the position of abortion in some Muslim majority states like Malaysia, Nigeria, Egypt, etc. is analysed. The study concludes with suggestions on the ways to ensure and affirm the right of the child to life through the strict observance of the Islamic law position regarding abortion.

\section{DEFINITION OF ABORTION}

\section{Juristic Views}

The Arabic word for abortion is al-Ijhadh. According to Duzy, ijhadh literally means to throw away something and in the language of scholars of jurisprudence, it means the discharge of a foetus from the womb

Ibn Qudama, Al-Kafi fii Fiqhu Ibn Hambal, vol. 4, (Egypt: Dar al-kutub alilmiyyah, 2010), 86; Ibn Rushd al-Qurtubi, Bidayatu al-Mujtahid wa Nihayatu alMuqtasid, vol. 2, (Misr: Al-halaby wa Awladahu, 1975), 416.

2 Abdulfatah Mahmud Idris, Al-Ijhad min Mandhur Al-Islamy Bahth Muqarana, (Egypt: Jamiatu al-Qahirah: 1990), at 22. 
before it develops. ${ }^{3}$ Accordingly, the scholars of fiqh (jurisprudence) use words such as al-inzāl, al-imlās, al-ikhrāj, al-isqāt, al-ilqā'a and al-istijhādh for abortion. ${ }^{4}$ Ibn Abidin, a Hanafi jurist, defined abortion as the act of removing a foetus from womb before it completes its gestation period. ${ }^{5}$

Islam is a unique religion amongst other religions in the world; this is because it covers all aspects of the human life both spiritual and mundane. ${ }^{6}$ The Qur'an states: "We have not neglected in the Book (the Qur'an) a thing. Then unto their Lord they will be gathered." Imam Ali interpreted this verse to mean Allah has left nothing unwritten in lauh al-mahfuz. ${ }^{8}$ While others opined that it means the Qur'an has left nothing unattended to. ${ }^{9}$ Like most aspects of the human life, the embryological development of humans has been extensively discussed and described in the divine scripture (the Qur'an) and commented on in detail by the Messenger of Allah (PBUH). ${ }^{10}$ Muslim jurists have equally given religious verdicts on issues bothering on embryological development and abortion. ${ }^{11}$ Muslim jurists continued, throughout the

3 Rainahat Duzy, Kalimah al-Mu'ajim al-Arabiyyah, vol. 7, (Iraq: Wazarah alThaqafath al-Ilan, 2000), 33.

$4 \quad \mathrm{Sa}$ 'ady Abu Jib, Al-Qamus al-Fuqhaha Lughatan wa Istilahan, (Damascus: Dar al-Fikr, 1988), 250.

Ibn al-Abideen, Risalah Ibn Abideen, Vol. 2, (Cairo: Bouleq Library, nd), 114.

With respect to ibadat (spirituality), it covers aspects relating to the worship of Almighty Allah. For examples all the five pillars of Islam (worshiping Allah alone and belief in His Messenger, prayer, fating, zakat and hajj) are well provided for by the Glorious Qur'an. Issues pertaining to muamalat (relationship between people) like trading, marriage, human rights etc, are equally provided for by the Qur'an and sunnah. See Krawietz Birgit, "Justice as a Pervasive System of Islamic Law", in Islam and the Rule of Law: Between Sharia and Secularization, eds. Krawietz, B. and Reifeld Helmut, (Berlin: ZME ,2003), 36.

Qur'an, Al-An'am:38.

8 Lauh al-Mahfuz is the book where all acts that are destined to happen are written. The Qur'an has referred to this book in several places. It is sacred and pure that no one touches it but the pure. The Qur'an states "None touch it except the purified [i.e., the angels]". Qur'an, al-Waqi'ah:79.

Tabari Muhammad., Jamiu al-Bayan fi Ta'wil Al-Qur'an, vol. 11, (KSA: Mauqiu Al-Jamiu, 2000), 346.

10 The Qur'an and the Sunnah are the primary sources of Islamic law. All other secondary sources of Islamic law are developed in line with the provisions of the glorious Qur'an and the traditions of the Prophet (PBUH) and they become valid only if they in conformity with the Qur'an and sunnah. See Kamali Mohammad Hashim, Principles of Islamic Jurisprudence, Rev. ed. (Cambridge: Islamic Texts Society, 1991), 7.

11 Fatwa is a religious verdict pronounced by a Muslim scholar. See Ul-Qadri, MuhdT., Fatwa on Suicide Bombing and Terrorism,(UK: Munhaj al-Qur'an International, 2010), 25. 
ages, to derive rules and methods of deducing new rulings on new issues. This allows Islamic law to be flexible in its application and accommodation towards certain local customs and needs. The issue of non-therapeutic and therapeutic abortion is no exception.

Abortion as a subject is not mentioned in any part of the Qur'an. However, the traditions of the Prophet (PBUH) as the second primary source of Islamic law is mostly relied on by scholars in forming opinion and passing verdicts concerning abortion under Islamic law. ${ }^{12}$ Abortion under Islamic law is the act of causing the discharge of a foetus (janin) not fully formed or causing the discharge of a fully formed foetus before the customary period. It is immaterial whether the foetus comes out dead or alive. ${ }^{13}$ Abortion has equally been defined under Islamic law as the deliberate termination of human pregnancy, the natural expulsion of a foetus from the womb before birth. ${ }^{14}$ An abortion may occur spontaneously, in which case it is also called a miscarriage, or it may be done intentionally, in which case it is often referred to as an induced abortion. ${ }^{15}$ It is clear from these definitions that under Islamic law, abortion is that act of terminating existence of the foetus by discharging it from the womb before it is born. A foetus comes into being under Islamic law when the male and female semen come together and fertilisation takes place. ${ }^{16}$ The Qur'an states: "So let man observe from what he was created. He was created from a fluid, ejected... emerging from between the backbone and the ribs." ${ }^{17}$ Muslim scholars explained that the male semen comes from his backbone while that of the female from her ribs. ${ }^{18}$

12 Hedayat Kamyar M., P. Shooshtarizadeh, and M. Raza. "Therapeutic abortion in Islam: contemporary views of Muslim Shiite scholars and effect of recent Iranian legislation." Journal of medical ethics 32, no. 11 (2006): 652-657.

13 Maudarbux Belall, Abortion in Islamic Law: Beyond the Pro-Life vs. Pro-Choice Debate, , accessed February 25, 2014, http://www.centuryassociation.org/belallmaudarbux/79-abortion-in-islamic-law-beyond-the-pro-life-vs-pro-choice-debate.

14 Demirel Serdar. "Abortion from an Islamic Ethical Point of View. "International Journal of Business and Social Science 2, no. 1 (2011): 230-237.

15 Ibid.

16 Abu Abdullah al-Qurtuby, Jamiu li ahkam Al-Qur'an, vol. 4, (Riyadh: Dar alim Al-Kutub, 2003), 20.

17 Qur'an, al-Tariq:5-7.

18 Imam Shawkany, Fathu al-Qadir, vol. 1, (Lebonon: dar al-Fikr, nd), 100; Ibn Kathir, Tasfir Qur'anal Azim, vol. 7, (KSA: daru tayyibatu linashri wal tawzi, 1999), 591; Abu Jafar al-Tabari, Jamiu al-Bayan fii Ta 'wil al-Qur'an, vol. 7, (KSA: Muassisatu al-Risalah, 2000), 591. 


\section{MEDICAL PERSPECTIVE}

Abortion is a matter of concern in the present day since the incidence of abortion is high in many parts of the world. For instance, induced abortion is very high in Russia, China and the former East European block countries, mainly because of the absence of the pill, and the use of abortion as a means of birth control. ${ }^{19}$ In Belarus, there are 200 abortions for each 100 live births, i.e. two-thirds of all pregnancies in the country end in abortion. ${ }^{20}$

Abortion has received various definitions from various bodies and experts. The World Health Organization (WHO) defines abortion as "the expulsion or extraction of a foetus or embryo weighing 500 grams or less from its mother." ${ }^{21}$ The Encyclopaedia Britannica of 1982 defined abortion as the termination of pregnancy before viability. ${ }^{22}$ Abortion has equally been defined to mean the intentional termination of a pregnancy after conception. It involves the act of killing the underdeveloped embryo or foetus. ${ }^{23}$ The meaning of abortion under Islamic law and the medical perspective is synonymous. Both look at abortion from the perspective of termination of pregnancy before the child is born. The discussion in this paper will be focused on induced abortion where the individual intentionally removes the foetus from the womb.

\section{ABORTION IN ISLAMIC LAW AND OTHER RELIGIONS}

The birth of a new baby is believed to be a gift from the Almighty that must be celebrated and accepted with gratitude. Abortion on the other hand goes contrary to the cherished custom of child birth. Even the books revealed before the Qur'an have mentioned the blessings in child birth. In the book of Genesis, God said to both Adam and Eve, "Be fruitful and increase in numbers, fill the earth and subdue it." 24

\footnotetext{
19 Albar Mohammed A. "Induced Abortion from an Islamic Perspective: Is it Criminal or Just Elective?." Journal of family \& community medicine 8, no. 3 (2001): 26.

20 Ibid.

21 Bennett Micheal. "Abortion” in Essentials of Obstetrics and Gynecology. eds. Neville F. Hacker and J. George Moore. (Philadelphia: Saunders Co., 1998), 479.

22 Encyclopedia Britannica. (UK: 1982), 1067.

23 "What is Abortion", accessed October, 19, 2013 www.civilliberty.about.com/od/ abortion/f/what abortion.htm .

24 Book of Genesis 1:27,28.
} 
In Islam, procreation is not only an integral part of matrimony; it is an act of worship. ${ }^{25}$ Even the sexual act with one's spouse is considered to be an act of ibadah (worship) as proclaimed by the Prophet (PBUH). ${ }^{26}$ The Qur'an speaks "O mankind, fear your Lord, who created you from one single soul and created from it its mate and dispersed from both of them many men and women. And fear Allah, through whom you ask one another, and the wombs. Indeed Allah is ever, over you, an Observer." 27

The Qur'an states further "And Allah has made for you from yourselves mates and has made for you from your mates sons and grandchildren and has provided for you from the good things. Do they then believe in falsehood and disbelieve the favour of Allah?" 28 The Messenger of Allah (PBUH) said in one of his narrations that: "Get married, beget and multiply because I will be proud of you among nations." ${ }^{29}$ He said in another Hadith: "Marry the kind and fertile, for I will be proud of your numbers among other nations."

Abortion has been a subject that is discussed in other religions. Though the position of some religions is similar to that of Islam, others are directly opposite. The Catholic tradition rejects "direct" abortion on the ground that it takes an innocent human life..$^{31}$ Although there are some discussions as to what counts as a direct abortion, the generally accepted view is that any intentional termination of a pregnancy is a direct abortion, whereas an "indirect" abortion occurs when a tubal pregnancy or a cancerous uterus is removed. In such a case, the death of the foetus would be viewed as the unintended consequence of an action intended to save the mother's life. ${ }^{32}$ Protestant's views and practise are particularly diverse when it comes to the issue of abortion. Conservative groups are among the most active in the pro-life movement, as many believe that life begins at conception. ${ }^{33}$ Some liberal denominations are pro-choice: they believe that principles such as the right to life and the freedom to choose must be applied and weighed by taking into

\footnotetext{
$25 \quad$ Albar Mohammed A., "An Islamic View on Contraceptive and Abortion", JIMA 21, (1989): 80.

26 Ibid.

27 Qur'an Nisa:1.

28 Qur'an Nahl:72.

29 Ibn Majah, Sunan Ibn Majah, Book 8.

30 Ibn Hanbal Ahmed, Ahmed Musnad.

31 Markwell Hazel J. and Barry F.Brown, "Bioethics for Clinicians: 27. Catholic bioethics", Can Med Assoc J,165, no.2 (2001): 190.

32 Ibid.

33 Pauls Merril and Roger C. Hutchinson, "Bioethics for Clinicians: 28. Protestant Bioethics”,), Can Med Assoc J 166, no. 3, (2002): 341.
} 
account the particular circumstances and that, during the first trimester, the decision to have an abortion should be between a woman and her doctor. ${ }^{34}$ Buddhists also oppose abortion, although there is no official stance but rather a general opposition to harming any life. ${ }^{35}$ Judaism allows abortion when the life of the mother is threatened, but otherwise considers it to be forbidden. ${ }^{36}$

The protection of the right of the child to life begins under Islamic law even before the child is born. ${ }^{37}$ This is by prohibition of abortion and any other act either from the child's parents or any other person that is likely to endanger the life of the child. ${ }^{38}$ Once a child is conceived, the law accords the foetus a special status and protection. The foetus according to Ibn Qudamah is that which is in the shape of a human being but has not fully developed into a complete human being. ${ }^{39}$ It has equally been defined by Qurtubi to mean that which is in the womb whether it is in a form of semen, clot blood or has developed into a human being. ${ }^{40}$ These views of Hanbali and Maliki scholars have shown that even if a foetus has not fully developed, it is entitled to be protected. This legal protection accorded to foetus under the Shari'ah is born out of the concept of dhimmah. ${ }^{41}$ Dhimmah is defined as "a quality by which a person becomes fit for what he [or she] is entitled as well as what he [or she] is subject to." ${ }^{42}$ The implication of this capacity is that it makes the foetus a repository of rights and obligations. It serves as prerequisite for ahliyyat al-wujub (the eligibility of a person to establish right for and obligation upon himself, technically called, receptive legal capacity). ${ }^{43}$ By this position the Shari'ah, has made itself clear to the effect that human life is sacred and its protection

\footnotetext{
$34 \quad$ Ibid.

35 Lecso Phillip A., "Buddhist View of Abortion", J Religion Health 26, no. 3, (1987): 214.

36 Lewis Judith A., "Jewish Perspectives on Pregnancy and Child Bearing", J Matern Child Nurs, 28 no. 5, (2003): 307.

37 Mansur, A.I.M., Huquq al-Tifl wa Aathaariha Baina al-shari'ah al-Islamiyyah wa al-Qanun al-Wada'iyyah,(Iskandariyyah: Dar al-Jami'at al-Jadeed, 2011), 2.

38 For example pushing a pregnant woman, scaring her or causing harm to her which will likely affect the fetus.

39 Ibn Qudama, Al-Kafi fii Fiqhu Ibn Hambal, 86.

$40 \quad$ Ibn Rushd al-Qurtubi, Bidayatu al-Mujtahid, 416.

41 Olowu Dejo, “Children's Rights, International Human Rights and the Promise of Islamic Legal Theory," Law, Democracy and Development 12, no. 2, (2008): 76.

42 Abdallah, A.A., Legal capacity in Islamic law (Zaria: Centre for Legal Studies, Monograph Series 1, 1978), 6.

43 Hurriyah El Islamy, Definition, accessed October 19,2013 www.kantakji.com/ fiqh/Files/Finance/N317.pdf .
} 
begins from the moment of conception. ${ }^{44}$

Ahliyyah al-wujub is divided into shakhsiyyah naqisah (incomplete receptive legal capacity) and kamilah (complete receptive legal capacity). ${ }^{45}$ The former applies to unborn child. This form of competence accords the unborn child with rights without corresponding responsibility. ${ }^{46}$ This gesture is in favour of the child due to his or her vulnerability. ${ }^{47}$ With respect to the latter, a person attains complete receptive legal capacity the moment he or she is born. That means such child has rights and corresponding responsibility. ${ }^{48}$

\section{Authority From the Qur'an, Sunnah and Juristic Views}

The Qur'an as the last massage from the Almighty to mankind has miraculously described the creation of man. ${ }^{49}$ These scientific facts were later discovered after over a 1000 years of the revelation of the Qur'an. ${ }^{50}$ The Qur'an states:

We created man of an extraction of clay, then We set him a drop in a safe lodging, then We created of the drop a clot, then we created of the clot a tissue, then We created of the tissue bones, then We covered the bones in flesh; thereafter We transformed it into another creature. So blessed be God, the Best of Creators." ${ }^{\text {51 }}$

Allah has made everything which $\mathrm{He}$ has created in the best of forms. He said in the Glorious Qur'an thus:

Who perfected everything which He created and began the creation of man from clay. Then He made his posterity out of the extract of a liquid disdained. Then He proportioned him and breathed into him from His [created] soul and made for you hearing and vision and hearts [i.e., intellect]; little are you grateful. ${ }^{52}$

44 Ibn Hazam Al-Andalusy, Al-Mahalla, Vol. 9, (Madinah: Dar al-Fikr Littibaa wal Wal-Tawzi, nd), at 221.

45 Zahraa Mahdi, "Legal Personality in Islam” Arab Law Quarterly, 10 ,no.3, (1995): 194.

46 Ibid.

47 Olowu Dejo, Children's Rights, International Human Rights, 76.

48 Ibid.

49 Naik Zakir A., Qur'an and Modern Science: Compatible or Incompatible (Kuala Lumpur: Saba Islamic Media, 2012), 49.

$50 \quad$ Ibid.

51 Qur'an, al-Hajj:12-14.

52 Qur'an: as-Sajda:7-9. 
The physical structure of Adam (who is the first man created by Allah) was from clay, then Allah breathed life into him..$^{53}$ His progeny was created from him and his spouse. ${ }^{54}$ The Prophet (PBUH) said:

\begin{abstract}
Verily the creation of any one of you takes place when he is assembled in his mother's womb; for forty days he is as a drop of fluid, then it becomes a clot for a similar period. Thereafter, it is a lump looking like it has been chewed for a similar period. Then an angel is sent to him, who breathes ruh (spirit) into him. This Angel is commanded to write four decrees: that he writes down his provision (rizq), his life span, his deeds, and whether he will be among the wretched or the blessed... 55
\end{abstract}

Based on these authorities, Muslim scholars agree that life is breathed into the foetus 120 days after conception. ${ }^{56}$ According to Al-Kuzāt, the soul is breathed into the foetus not after the egg is fertilised, but forty-two nights after the Nutfah has settled down in the womb. This is because the Nutfah settles in the womb when it holds onto the wall of the womb, approximately on the seventh day after conception. Thus, the breathing of the soul occurs after the fourty-ninth night, approximately at the beginning of the eighth week. ${ }^{57}$

It is clear that the ensoulment of a foetus appears to be after forty days. However, the period which goes beyond forty days has not been determined absolutely. Therefore, it is impossible to ascertain a specific day for the breathing of the soul. Nonetheless, it is most probable that the soul is breathed in between the first fourty and fifty days. According to Muslim scholars, there is no doubt that ensoulment does not take place before it. ${ }^{58}$

\footnotetext{
53 Alkhalid, S.A., Siratul Adam, (Oman: Alwiraq, 2003), at 25.

54 Naik, Zakir A., Qur'an and Modern Science, 49.

55 Muslim, H., hadith 2643.

56 It is however believed that the foetus is attached to the mother right from conception up to delivery. In other words, the life of the foetus is inseparable from that of the mother. See Ahmad, B. Q., Huquq At-Tiflu Fii Ashariatu Al-Islamiyatu,(Libya: Maktabatu al-Wataniyatu Lil Bahthi Wa-Tatwir, 2005), 20.

57 Abu Abdullah al-Qurtuby, Jamiu li ahkam Al-Qur'an, 6-7; Ibn Kathir, Tasfir Qur'anal Azim, 202-207; Abu Zakariyya al-Nawawi, Al- Munhaju Sharhu Sahihu Muslim Ibn Hajjaj, vol. 16, (Beirut: Dar al-Ihyau Turath al-Arabiy, 1392), 120; AlKuzāt S. Mehmud, Cenine Ruh Ne zaman Verilir?, Diyanet İlmi Dergi, v.38, AprilJune, 2002, cited in Demirel Serdar. "Abortion from an Islamic Ethical".

58 Abdul-rahman Al-Suwuty, Al-Deebaju alaa Sahihu Muslim Ibn Al-Hajjaj, vol. 6, (AlKhabar: Dar Ibn al-Affan, 1996), 5; Abu Zakariyya al-Nawawi, Al-Munhaju Sharhu Sahihu Muslim Ibn Hajjaj, 122; Demirel Serdar. "Abortion from an Islamic Ethical”.
} 
The ascertainment of the stage of pregnancy is very important in the determination of the permissibility of abortion on certain grounds. Generally, abortion is unlawful under Islamic law. ${ }^{59}$ All the four major sunni schools of Islamic jurisprudence have agreed that abortion is generally haram in Islam. ${ }^{60}$ This is because it involves the termination of pregnancy. According to Ibn Jawziyyah, when the womb has retained the semen, it is not permitted for the husband and wife, or one of them or the master of the slave-wife, to induce an abortion. After ensoulment, however, abortion is prohibited absolutely and is akin to murder. ${ }^{61}$ Ibn Taymiyah, opined that: "It is the consensus of all fuqaha (Muslim jurists) that abortion is prohibited." ${ }^{2}$ In a similar vein, Imam Al-Ghazali, stated that it is a crime to disturb the fertilized egg of a human being. ${ }^{63}$ In the words of Qardawi, "While Islam permits preventing pregnancy for valid reasons, it does not allow doing violence to it once it occurs." ${ }^{64}$ This opinion is based on the position that the companions of the Prophet (PBUH) practiced cortus intereptus during the life time of the Prophet (PBUH) and he did not stop them. ${ }^{65}$ This practice is akin to the modern practice of family planning, in the sense that it is a step that is taken to avoid pregnancy without the use of contraceptives.

Under the Shiite doctrine, life is believed to be breathed into the foetus after about 4 months of conception. Abortion is forbidden before the 4 months except if continuation with the pregnancy becomes intolerable to the mother. ${ }^{66}$ The prohibition becomes even more serious after the 4 months. It is opined under this doctrine that after the expiration of the 4 months, abortion is totally forbidden except if

\footnotetext{
59 Zain al-Deen ibn Najeem al-Hanafi, Bahr al-Rahiq Sharh kanz al-Daqaaiq, Vol. 8, (Beirut: Dar al-Marifah, nd), 233; Imam Shawkany, Fathu al-Qadir, 102. Shapiro, Gilla K., "Abortion in Muslim Majority Countries: An Overview of the Islamic Discourse with Policy Implications", Health Policy and Planning 10,(2013):1093.

60 Ibid.

61 Al-Kuzāt S. Mehmud, Cenine Ruh Ne zaman Verilir?.

62 Majid K.A., Islam and Abortion, accessed February 26, 2014. https:/www.spuc. org.uk/about/muslim-division/prohibit.

63 Muhammad al-Ghazali, Ihyau Ulum al-deen, (Beirut: Dar al-Marifah, 1993), 107.

64 Al-Qaradawi Yusuf., The Lawful and Prohibited in Islam, (al-halal wal Haram Fi al-islam), trans.Kamal El-helbawy,M. Moinuddin Siddiqui, Syed Shukry , (Kuala Lumpur: Islamic Book Trust, 1995), 229.

65 Sahih Bukhari vol. 7, hadith 135 and 136; Whaley Zoe, "Birth Control and Abortion in the Practice and tradition of Islam", Macalester Islam Journal , 2, no.3, (2007): 3 .

66 Aramesh Kiarash, “A Shiite Perspective Toward Abortion”, DARU Journal of Phamaceutical Sciences 14, no Suppl.1, (2006): 38.
} 
that will endanger the life of the mother and the foetus. ${ }^{67}$ With respect to pregnancy that is due to zina (adultery and fornication) or rape, abortion is totally forbidden. ${ }^{68}$

The punishment for abortion under Islamic law is not like murder. ${ }^{69}$ Under Islamic law, the person that has caused the abortion has to pay diyyah (blood money) if the foetus is born alive and dies subsequently. ${ }^{70}$ But if the foetus is not completely formed, then a lesser fine is to be paid by the wrong doer. ${ }^{71}$ The position is the same even if it is the mother that is responsible for the abortion without the father's consent.

The penalty for unlawful abortion in Islamic law is a ghurra, which is five camels or its monetary equivalent (50 dinars or 500 dirhams). ${ }^{72}$ This rule is based on the Prophetic judgment where a woman assaulted a pregnant woman and killed her as well as her baby; the Prophet (PBUH) condemned the offender to pay a ghurra for the killing of her foetus and a diyyah (100 camels) for homicide. ${ }^{73}$ According to Ibn Qudamah, a Hanbali scholar, if the abortion occurs while the foetus is still in the gastrula stage, and expert midwives testify that it has formed the shape of a human being, then the ghurra will be paid but if it has

$\begin{array}{ll}67 & \text { Ibid. } \\ 68 & \text { Ibid, } 39 . \\ 69 & \text { With respect to murder, where the murder intentionally kills his victim, the law }\end{array}$ of retribution applies. That means the murderer will also be killed. This is based on the provisions of the Qur'an which states "O you who have believed, prescribed for you is legal retribution for those murdered the free for the free, the slave for the slave, and the female for the female. But whoever overlooks from his brother [i.e., the killer] anything, then there should be a suitable follow-up and payment to him [i.e., the deceased's heir or legal representative] with good conduct. This is an alleviation from your Lord and a mercy. But whoever transgresses after that will have a painful punishment." Qur'an, Al-Baqarah:178. The Qur'an states further “And We ordained for them therein a life for a life, an eye for an eye, a nose for a nose, an ear for an ear, a tooth for a tooth, and for wounds is legal retribution. But whoever gives [up his right as] charity, it is an expiation for him. And whoever does not judge by what Allah has revealed then it is those who are the wrongdoers [i.e., the unjust]." Qur'an Maida: 45 70 Muhammad Arafah al-Dasuqi, Hashiyatu al-Dasuqi alaa Sharh al-Kabir, Vol. 4, (Beirut: Dar al fikr, nd), 268; Ibn Maudud Musally, Al-Ikhtiyar tahmil al-kitab, vol. 1, (Syria: Dar Risalah al 'alamiyyah, 2009), 53; Imam al-Nawawi, Rawdat al-Talibina wa Umdatu al-Muftina, vol. 3, (Beirut: maktab al-Islamiyy, 1984), 409; Whaley Zoe, "Birth Control and Abortion", 65.

71 Ibid.

72 With respect to murder, the Prophet (PBUH) said "And whoever kills a believer, retribution is due on him except if the wali of the murdered pardon him. And for a life, his diyyah is a hundred camels..." see Al-Suyutị, Sharh Sunān al-Nasa' $\bar{\imath}$, Vol. 8,(Beirut: Dār al-Bashair al-Islāmiyyah, 1994), 58.

73 Sunan Abu Dawood, vol 4, hadith 4582. 
not formed the shape, then indemnity in the form of ghurra shall not be paid. ${ }^{74}$ Ibn Taimiyyah on the other hand opined that in addition to the blood money, the person responsible for the abortion must expiate the manslaughter by fasting for two consecutive months as provided by Qur'an, Nisa: 92. If the mother is the one responsible for the abortion she must pay the blood money to the heirs of the foetus. If she does not have a slave for manumission then she must fast for two months consecutive or feed 60 people. ${ }^{75}$ The Hanafi School on the other hand opined that if a person strikes the stomach of a pregnant woman and caused miscarriage, he must pay blood money but if it is by accident or the husband pardons him, then there is no need to pay blood money. ${ }^{76}$ The Zahiri School on the other hand hold the view that diyyah is paid if the pregnancy is not up to 4 months, but after 4 months, the person responsible will face reprisal (qisas) or payment of full diyyah. ${ }^{77}$ The payment of penalty becomes binding provided that the aborted child is dead when it came out, irrespective of whether the person inducing the abortion was the mother or any other party. If the woman was pregnant with more than one child, then for each child, one penalty applies. ${ }^{78}$ The ghurra is paid to the family or heirs of the foetus. This is because under the Shari'ah, just like in the case of homicide, the personal legal heirs of a deceased are entitled to be paid the blood money. ${ }^{79}$ There is no distinction in this regards between a male and a female. If it is twins, the ghurra shall be two; each foetus is entitled for its separate payment. Where one of the foetus is born alive and then dies subsequently, full diyya will be paid for the one born alive and ghurra be paid for the one that was aborted dead ${ }^{80}$ All the principles of inheritance apply to a foetus if it is born alive. ${ }^{81}$ This rule is informed by the fact that

\footnotetext{
74 Ibn Qudama, , Al-Kafi fii Fiqhu Ibn Hambal,120.

75 Albar, Albar Mohammed A., "Induced abortion from an islamic", 27.

76 Ali ibn Abu bakr al-Murgiinany, Al-Hidayah wa-al-Kifayah, vol. 9, (Beirut: tab atu dar ihya al-Turath al-Araby, nd), 238; Mahammad alaa'a al-deen al-haskafy, Radd al-Mukhtar, vol. 5, (Beirut: dar Kitab al-Ilmiyyah, nd), 378; Zain al-Deen Ibn Najeem, Bida 'iu al-Sanai, vol. 7, (Beirut: Dar-Al-Marifah, nd), 326.

77 Ibn Hazam Al-Andalusy, Al-Mahalla, 22; Atighetchi Dariusch, Islamic Bioethics: Problems and Perspectives,(Netherlands: Springer, 2007), 102.

78 Maudarbux Belall, Abortion in Islamic Law.

79 Muhammad Arafah al-Dasuqi, Hashiyatu al-Dasuqi alaa Sharh al-Kabir, 268; Ibn Maudud Musally, Al-Ikhtiyar tahmil al-kitab, 53; Imam al-Nawawi, , Rawdat alTalibina , 409.

80 Abu Hasan al-Maliky, Kifayatu al-Talibu al-Rabbani lirisalati Abu Zaid alQairawani, vol. 2, (Beirut: Dar alFikr, 1996), 406.

81 Muhammad Khatib al-Sharbiny, Mughny al-Muhtaj, vol. 3, (Beirut: Dar al-Fikr, nd), 5 .
} 
it has a life and could have developed into a complete human being. ${ }^{82}$ This therefore underscores the argument that abortion is tantamount to infringement of the child's right to life.

There is no distinction between a pregnancy of a lawful marriage and that of extra marital relationship when it comes to the payment of ghurra or diyyah as the case may be ${ }^{83}$ There is however divergent opinions on the position of children of Ahl al-Dhimmiyah (non-Muslims under Islamic state). According to the Hanafi and Zahiri Schools, there is no distinction between Muslims and Ahl al-Dhimmiyah when it comes to the payment of ghurra, meaning the amount to be paid for a Muslim is the same with that of a non-Muslim. ${ }^{84}$ The Shafi'i School opined that non-Muslims are entitled to one third of that of a Muslim child or foetus. ${ }^{85}$ The Maliki and Hambali Schools opined that the ghurra shall be one tenth of its mother's diyyah ${ }^{86}$ These opinions have further added weight to the fact that abortion is indeed an infringement of the right of the child to life which necessitates the need for the payment of blood money for such infringement.

\section{The Extent to Which Abortion is Allowed in Islamic Law}

Though the general rule is that abortion is unlawful under Islamic law, Muslim scholars have however opined that situations can arise where abortion can be justified. They however differ on the grounds or reasons that could allow abortion and the stage of the pregnancy that should be the determinant factor. The Hanafi School permits abortion until the end of the fourth month. According to the school, a pregnant woman could have an abortion without her husband's permission, but she should have reasonable justification for this act. ${ }^{87}$ One reason, which is mentioned frequently, is the presence of a nursing infant. A new pregnancy put an upper limit on lactation, and the jurists believe that if the mother could not be replaced by a wet-nurse, the infant would die. ${ }^{88}$

\footnotetext{
82 Ahmad ibn Salim al-Nafrawy, Al-Fawakihu al-Dawwani alaa Risalah ibn Abi Zayid al-Qayrawany, vol. 2, (Madinah: Maktab Thaqafah a-Diniyyah, nd), 696.

83 Muhammad Arafah al-Dasuqi, n. 70, at 260.

84 Ibn 'Abidin, Rad al-Mukhtar, vol. 28, (Beirut: Dar al-Fikr, 1992), 201; Ibn Maudud Musally, Al-Ikhtiyar tahmil al-kitab, vol. 1, 50.

85 Imam al-Nawawi, Rawdat al-Talibina ,370; Muhammad Khatib al-Sharbiny, Mughny al-Muhtaj 102.

86 Muhammad Arafah al-Dasuqi, Hashiyatu al-Dasuqi alaa Sharh al-Kabir 269; Ibn Qudama, Al-Kafi fii Fiqhu Ibn Hambal ,86.

87 Zain al-Deen Ibn Najeem, Bida'iu al-Sanai 326; Aramesh Kiarash, “Abortion: An Islamic Ethical View”, Iran J Allergy Asthma Immunol 6, Suppl.5, (2007): 31.

88 Ibid.
} 
For the Maliki School, an abortion is permissible with the consent of both parents up to 40 days of conception; it is no longer allowed after that ${ }^{89}$ A number of the Maliki jurists described abortion as completely forbidden. In their view, when the semen settles in the womb, it is expected to develop into a living baby and it should not be disturbed by anyone..$^{90}$ The Shafi'i school ${ }^{91}$ allows abortions to be performed up to day 120 days. ${ }^{92}$ Ibn Abidin said, the legality of abortion is dependent upon the validity of the reason. ${ }^{93}$ Ibn Najeem pointed out that Shar'iah does not permit the killing of a soul for the purpose of saving another soul. ${ }^{94}$ The implication of this view is that even if the life of the mother is at risk, killing or aborting the foetus may not be allowed because it amounts to killing a soul. However, this position will apply only after ensoulment has taken place with regards to the foetus.

In principle, nowadays the protection of the life of the unborn is again brought to the front burner in the discourses on abortion. Exceptions are made in some countries if the life of the mother is endangered, based on the Qur'anic provision which states that: "A mother should not be made to suffer because of her child." 95 The argument therefore revolves around permissibility of abortion for whatever reason before the 120 days of conception. The Council of Islamic Jurists of Mecca issued a fatwa in 1990 which allows abortion in cases of serious congenital malformations provided that it has been agreed by a medical committee of specialist doctors, and prior to 120 days computed from conception (134 days from the woman's last menstrual period) only if there is no available treatment for the foetus or baby. ${ }^{96}$ In Egypt however, the former Grand Sheikh of Azhar Sharrif, Sheikh Saeed Muhammad Tantawi issued a fatwa in June 2004 supporting a proposed law making rape a ground for allowing abortion. That brought serious controversy

\footnotetext{
89 Muhammad Ibn Ahmad al-Qurnaty, Qawanin al-Fiqhiyya, (Beirut: dar al-Ilmiyya, 1988), 235; Muhammad ibn Yusuf al-Abdary, Al-Taju wa al-Iklil, vol. 2, (Beirut: Dar al-Fikr, 1398H), 622; Ibrahim B. Syed., Abortion, accessed October 20, 2013. http:// www.irfi.org/articles/articles_101_150/abortion.htm .

$90 \quad$ Ibid.

91 Ibid.

92 Ibid.

93 Ibn 'Abidin, Rad al-Mukhtar, 202; International Planned Parenthood Federation, Middle East and North Africa Region, Islam and Family Planning Vol. 2,(Cairo: International Planned Parenthood Federation, 1974), 273.

94 Zain al-Deen ibn Najeem al-Hanafi, Bida'iu al-Sanai 233; Abdulfatah Mahmud Idris, Al-Ijhad min Mandhur Al-Islamy Bahth Muqarana ,100.

95 Qur'an, al-Baqarah:233.

96 Alireza Bagheri and Leila Afshar, "Abortion in Different Islamic Jurisprudence: Case Commentaries", Asian Bioethics Review Vol.3 no. 4, (2011): 360-361.
} 
among Muslim jurists in Egypt. For instance, the then Mufti of Egypt Ali Gomaa said that Tantawi's opinion is contrary to the teachings of the Qur'an and the practice of the Prophet (PBUH) and his companions which prohibit the killing of innocent soul. ${ }^{97}$ With the advancement of technology, the excuse for abortion on grounds of rape cannot hold water. This is because the victims of rape can simply use RU486 (the "morning-after pill"), as long as it could be reasonably assumed that the fertilized egg has not become implanted on the wall of the uterus. ${ }^{98}$

Several congenital abnormalities cannot be detected in the uterus, especially before 4 months of gestation, with much accuracy. ${ }^{99}$ Almost

\section{$97 \quad$ Aramesh Kiarash, "A Shiite Perspective Toward Abortion”, 39.}

98 The following are some maternal diseases that could pose a threat to the safety of the mother or the child or to both the mother and the child. Valvular heart disease, function class III or IV heart failure, which are not reversible to function class II; Noncoronary acute heart problem, function class III or IV failure, such as myocarditis and pericarditis; Any history of dilated cardiomyopathy in previous pregnancies; Marfan syndrome accompanied by ascending aorta diameter $>5 \mathrm{~cm}$; Eisenmenger syndrome; Gestational fatty liver; Oesophageal varices (grade III); History of bleeding from oesophageal varices after portal hypertension; Uncontrollable autoimmune hepatitis; Renal failure; Hypertension (uncontrollable with permitted drugs in gestation period); Any pulmonary diseases such as emphysema, fibrosis, kyphoscoliosis, diffuse bronchiectasis with pulmonary hypertension even in the mild form; Hypercoagulability in which heparin administration may worsen the mother's existing life-threatening disease; HIV infection that has entered the AIDS disease phase; Uncontrollable active lupus with the involvement of a major organ; Vasculites with the involvement of major organs; All space-occupying lesions of the central nervous system in which beginning treatment causes danger to the fetus and not beginning treatment causes danger to the mother; Phemphigus vulgaris, severe and generalised psoriasis and end-stage melanoma, which leads to serious fatal danger for the mother; Epilepsy that is resistant to treatment, despite giving multiple drugs. In addition to the mentioned disease conditions that are threat to safety of the mother and her baby, the following are equally categorized as fatal conditions: Osteogenesis imperfect; Osteochondrodysplasia; Infantile osteopetrosis (malignant form); Bilateral renal agenesis; Polycystic kidney (recessive form); Multicystic dysplastic kidneys; Potter's syndrome; Congenital nephrotic syndrome (with hydrops); Chromosomal disorders leading to degenerative lesions and brain and kidney involvement, such as vertebrae, anus, cardiovascular tree, trachea, oesophagus, renal system and limb buds (VACTERL) syndrome; Severe bilateral hydronephrosis; $\alpha$-thalassaemia with hydropsis fetalis; Homozygote thrombotic disorders (ie, protein $\mathrm{C}$ or factor V Leiden deficiency); Trisomy 8; Trisomy 13; Trisomy 16; Trisomy 18; Trisomy 3; Anencephaly; Fetal hydrops; Crie du Chat syndrome; Holoprosencephaly; Syringomyelia; Cranioschisis; Meningoencephalocele or hydroencephalocele; Thanatophoric dysplasia; Holoprosencephaly; Ichthyosis congenital neonatum; Schizencephaly; Exencephalia. See Hedayat Kamyar M., P. Shooshtarizadeh, and M. Raza. "Therapeutic abortion in Islam", 626.

99 Kimberly D. Gregory, Jennifer R. Niebyl, and Timothy RB Johnson, 
$90 \%$ of cases of central nervous system defects (i.e., holoprosencephaly and anencephaly) are detected after 24 weeks of gestation, whereas the absolute cut-off date for abortions in Islam is 4 months or 4 months and 10 days at most. ${ }^{100}$ Serum marker tests for Down's syndrome (trisomy 21) and neural tube defects are not carried out until after 15 weeks of gestation at the earliest. ${ }^{101}$ These challenges make it difficult for congenital abnormalities to be ascertained at the early stage of the pregnancy.

The discussion has clearly pointed out the fact that Muslim scholars are not unanimous on the grounds that could allow abortion and the stage at which abortion can be permitted. An opinion shared by almost all the jurists is that the threat to the life of the mother is a justification for induced abortion no matter the stage of the pregnancy. Any abortion after ensoulment must be based on strong medical reason.

\section{ABORTION AND THE LAWS OF SELECTED MUSLIM COUNTRIES}

The Muslim nations of the world are under the umbrella of the Organisation of Islamic Cooperation (OIC). ${ }^{102}$ The OIC is made up of 57 members with Muslim majorities or pluralities. ${ }^{3}$ Most Muslim member countries of the OIC have restrictive abortion laws that permit abortions only when the life of the mother is threatened. ${ }^{103}$ Twelve members of OIC allow unrestricted access to abortion. ${ }^{104}$ Among the

\footnotetext{
"Preconception and Prenatal Care: Part of the Continuum" ineds. "Obstetrics-Normal and Problem Pregnancies, eds. Gabbe, S.G., Neibyl J.R., Simpson, J.L. 4th edn. (New York: Churchill Livingstone, 1997), t 254-256.

100 Hirsch J F, , "Medical abortion: Ethics, Laws and Religious Points of View.", , J Childs Nerv Syst, Vol. 12, no. 9 (1996) 507.

101 See accessed February 27,2014,www.idph.state.il.us/.../maternal_serum.htm .

102 The OIC is an inter-governmental organization comprised of Islamic states with its headquarters in Jeddah, Saudi Arabia. It was founded in September 1969, following an appeal from the former Mufti of Jerusalem to all Islamic states to join the First Islamic Summit at Rabat, Morocco. The summit was held in response to the August arson attack on the holy al-Aqsa Mosque in Jerusalem by Israel. See Hansen D.A. and Hemmasi, M., The State of the Organization of Islamic Conference at the Dawn of the New Millennium, accessed February 28,2014, pcag.uwinnipeg.ca/PrairiePerspectives/PP-Vol04/Hansen-Hemmasi.pdf.

103 Rita James Simon, Abortion: statutes, Policies, and Public Attitudes the World Over,(USA: Greenwood Publishing Group,1998), 3.

104 Hedayat Kamyar M., P. Shooshtarizadeh, and M. Raza. "Therapeutic abortion in Islam”, 626 .
} 
socially conservative Muslim countries, seven of them permit abortion in the first 4 months of gestation for foetal deformities; four countries in sub-Saharan Africa (Benin, ${ }^{105}$ Burkina Faso, ${ }^{106}$ Chad and Guinea) and three in the Middle East (Kuwait, Qatar and Iran). ${ }^{107}$

Most Muslim countries have categorically decreed abortion as offence. In Malaysia for instance, abortion is generally an offence punishable by law. ${ }^{108}$ The Malaysian Penal Code states that a termination of pregnancy is permitted in circumstances where there is risk to the life of the pregnant woman or threat of injury to her physical or mental health. ${ }^{109}$ The Malaysian Department of Islamic Development (JAKIM) and has given fatwa to the effect that abortion is haram in Islam. ${ }^{110}$ However, where the pregnancy has not reached 120 days, abortion can be allowed for overriding medical reasons. However, after 120 days, abortion is totally prohibited except if the pregnancy will endanger the life of the mother. The Dialogue Fatwa Committee of the National Council for Islamic Religious Affairs Malaysia in its 52nd meeting held on July 1, 2002 issued fatwa on the legality of abortion for rape victims. They concluded that it is illegal if the foetus is older than 120 days since at this stage the foetus has been blown the spirit. ${ }^{111}$ Illegal sexual relations is not an excuse for abortion in Malaysia. ${ }^{112}$ In Nigeria,

105 Article 17 of Law No. 2003-04 on sexual and reproductive health of 24 January 2003.

106 Article 383 -390 Loi No. 043/96/ADP du 13 Novembre 1996 portant Code Pénal 107 Women Waves, Abortion Laws World Wives, accessed February 28, 2014.http:// www.womenonwaves.org/en/page/460/abortion-laws-worldwide .

108 Ahmad Bin Muhammad Husni, Abdul Basir Mohammad, Amir Husin Mohd Nor, Hayatullah Laludin and Mohd Al Adib Samuri, "Abortion in Malaysian law: A Comparative Study with Islamic Jurisprudence", Advances in natural and applied sciences, 7, no.1,(2013): 41.

109 Section 312 of the Malaysian Penal Code

110 September 30, 2014, http://www.e-fatwa.gov.my/blog/hukum-pengguguran accessed. Athar, S., et al., "Islamic Medical Ethics: The IMANA Perspective", (2005), Vol. 37, JIMA, at 39. See also Akbar, K.F., Family Planning and Islam: A Review available at www.muslimcanada.org/family.pdf viewed on 17 October, 2013.

11 Accessed September 30. 2014, http://www.e-fatwa.gov.my/blog/hukumpengguguran.

112 Umi Adzlin, Azizul A, Uma V, Nor'Izam A, "Termination of Pregnancy for a Muslim rape Victim and Dilemma in Malaysia Setting: Case Report", , Malaysian Journal of Psychiatric,21 no.1 (2012) accessed November 27, 2013 www.mjpsychiatry. org/index.php/mjp/article/view/205/153 . 
the Penal Code ${ }^{113}$ and the Criminal Code ${ }^{114}$ have prescribed protection for children even before their birth by prohibiting abortion. Under the two codes, abortion is an offence punishable by law. According to the Criminal Code:

Any person who, with intent to procure miscarriage of a woman whether she is or is not with child, unlawfully administers to her or causes her to take any poison or other noxious thing, or uses any force of any kind, or uses any other means whatever, is guilty of a felony, and is liable to imprisonment for fourteen years. ${ }^{115}$

Similarly, the provisions of the Penal Code is in pari materia with that of the Criminal Code with respect to the punishment of fourteen years prescribed for the offence except for the fact that under the Penal Code, the punishment does not change whether the woman herself or someone else is charged. Unfortunately, the Penal Code appears to lack provision for attempted abortion by anybody because the wordings of the law are clear to the effect that "whoever voluntarily causes a woman with child to miscarry..." 116 The criminalisation of abortion stems from the fact that a child is presumed to deserve the protection of the law even before birth. Though abortion is not as bad as infanticide, yet the law looks at it from the perspective of the protection of the foetus and the fact that a botched abortion has health implications for the putative child. ${ }^{117}$

The Algerian Penal Code provides: "Therapeutic abortion may be carried out only subject to the provisions of Section 28 of this Code in cases where the mother's life is in danger or her health is seriously threatened and the operation is likely to save her life." 118 The Pakistani Penal Code ${ }^{119}$ on the other hand, makes it an offence carrying a discretionary sentence ( $t a{ }^{\prime} z \bar{l} r$ ) of three to ten years prison if done

113 The Penal Code applies in the northern states of Nigeria which is predominantly Muslims. Due to the Muslim background of the region, the Penal Code is significantly influenced by the principles of Islamic law. See Peters R., The Re-Introduction of Islamic Criminal Law in Northern Nigeria, accessed February 28, 2014 rezaei.typepad. com/hassan_rezaei/.../islamic-criminal-law-nigeria_en.pdf.

114 The criminal Code applies in the states of southern part of Nigeria.

115 Section 228 Criminal Code.

116 Section 232 Penal Code.

117 That affects the child in many ways which can lead to disability.

118 Article 414(1) of the Algerian Penal Code, subsection 2 defined "Therapeutic abortion" to mean the induced termination of pregnancy for therapeutic purposes before the foetus is viable.

119 Article 338 A-G of the Pakistani Penal Code. 
without the woman's consent. It is allowed in the first trimester if the woman's health is endangered.

In Egypt, ${ }^{120}$ Iran, ${ }^{121}$ Pakistan and Turkey ${ }^{122}$ abortion is fully prohibited (an exception is made if the mother's life is endangered). This does not imply, however, that abortions are not at all performed. Tunisia's liberal abortion practice allows for abortions to be performed up to the end of the third month. ${ }^{123}$ Therefore, abortions are principally permissible for single as well as married women in the first three months, provided that a registered doctor performs them. The approval of the husband or of a male guardian is not required in Tunisia. ${ }^{124}$

In Morocco it is a crime except where the mother's life is in danger; in that case, it will be allowed in the first trimester. ${ }^{125}$ In Bahrain ${ }^{126}$ and Jordan $^{127}$ it is allowed if the mother's health is imperilled. Severe foetal

120 See section 260-264 of the Egyptian Penal Code and Code of Ethics, Regulation No. 238 of 21 March 2003 of the Ministry of Health and Population.

121 See, Law on Islamic Penalties 1991, Law No. 586, Book Four: Compensation (diye), Section Twelve: Compensation (diye) for miscarriage. Law of Jun. 15 June 2005 provides Single Article-Permission for an abortion shall be issued only if three expert physicians decide, and the coroner's office approves, that the fetus has symptoms of mental retardation or some physical abnormality that makes the life of mother miserable and/or that a certain disease is seriously threatening and endangering the life of the mother, that the infant is less than four months old, and that the mother agrees to the abortion. Under these terms, the physician performing abortion is free from responsibility or penalty of any kind. The above article has been ratified in the public session held on Tuesday 31 May 2005 in the Islamic Council Majlis and has been approved by the Guardian Council on 15 June 2005 accessed March 1, 2014 http://www.hsph.harvard.edu/population/abortion/Iran.abo.html.

122 Law No. 2827 of 24 May 1983, Population Planning Law, Art. 3. A womb evacuation can be performed on request, up to the 10th week, on condition that there is no medical objection from the standpoint of the woman's health.

123 Ibrahim B. Syed, Abortion.

124 Ibid.

125 See Chapitre VIII, Section I, Article 449-448 of Morocco Code Pénal of 26 November 1962 as amended by Law No. 181-66 of 1 July 1967.

126 Section 321 of Bahrain Penal Code of 20 March 1976 provides "Whoever performs an abortion on herself without the consultation of a physician or without the physician's knowledge shall be punished with up to six months' imprisonment or with a fine of up to 50 dinars."

127 Section Article 324. A woman who performs an abortion on herself in order to save her honor shall benefit from a mitigation of punishment. Similarly, "A person who performs any of the acts described in Articles 322 and 323 in order to preserve the honor of a descendant or a relative to the third degree shall benefit from the same mitigation" Jordan Penal Code of 10 April 1960, see also Public Health Law, 2008. See also Medical Guidelines under Article 16 of the Medical Association Law (Law No. 3/1970). 
deformity is sufficient cause for abortion in Iraq. ${ }^{128}$ Though abortion on health grounds is allowed in most parts of the world, the only places in the world where abortion is illegal even if the mother's life is in danger are the Vatican, Chile, El Salvador and Malta. ${ }^{129}$

\section{CONCLUSION}

Abortion in Islam is prohibited because it is an abuse of the right of the child to life. Though not developed into a complete human being, the foetus must be allowed to be born alive and healthy. Muslim jurists agree that abortion could be permitted if there is a threat to the life of the mother especially, when the pregnancy is less than 120 days. After that, the prohibition becomes even more serious due to the belief that life is breathed into the foetus. Any person responsible for the act of abortion will be punished accordingly, thought not in the same manner as homicide. The diyyah to be paid becomes higher if the foetus if aborted alive and dies subsequently. Rape is generally not an excuse for abortion according to majority opinion. However, some Muslim jurists permit abortion under such circumstances if the pregnancy does not exceed 120 days, i.e. it is permissible under certain circumstances if carried out before ensoulment at 4 months of gestation and after that to save the life of the mother.

With the development of the cutting-edge technology, it is easy to know the state of the pregnancy at an early stage. It is therefore better to take a decision on whether to keep the pregnancy or abort it before it exceeds the 120 days. Governments should also take appropriate measures to monitor hospitals closely and to ensure that abortions are not illegally carried out. If doctors are found guilty of abortion, appropriate sanctions such as suspension of medical practice license, demotion, etc. must be taken against them. The punishment for abortion must not just remain in the books, the courts must be seen pronouncing such sentences on accused persons and such judgements must be enforced to the letter.

\footnotetext{
128 See section 417 and 418 of the Iraqi Penal Code of 19 August 1969.

129 Maria Elena Acuna Moenne and Matthew Webb, "Embodying Memory: Women and the Legacy of the Military Government in Chile", Feminist Review, 79, (2005): 150 .
} 
